\title{
Progress and challenges in the direct carbon fuel cell technology
}

\author{
Junjie Chen*, Xuhui Gao, Longfei Yan, Deguang Xu
}

School of Mechanical and Power Engineering, Henan Polytechnic University, Jiaozuo, Henan, China

*E-mail address: comcjj@163.com, comcjj@yahoo.com

Keywords: Fuel cell; Coal; Biomass; Power generation; Carbon dioxide capture

\section{ABSTRACT}

Fuel cells are under development for a range of applications for transpon ationary and portable power appliances. Fuel cell technology has advanced to the stage where con reia field trials for both transport and stationary applications are in progress. irect rbon Cells (DCFC) utilize solid carbon as the fuel and have historically attract ot vestme than other types of gas or liquid fed fuel cells. However, volatility in gas ap an con dity rices and the increasing concern about the environmental impact of burn heavy fos cuels for power generation has led to DCFCs gaining more attention within th glob udy community. A DCFC converts the chemical energy in solid carbon direc, nto ele vity through its direct electrochemical oxidation. The fuel utilization can be Imost $100 \%$ as $y$, fuel feed and product gases are distinct phases and thus can be easily separa $d$. This is npt the case with other fuel cell types for which the fuel utilization within the cell is typ lly limite to below $85 \%$. The theoretical efficiency is also high, around $100 \%$. The combination wo factors, lead to the projected electric efficiency of DCFC approaching 80 anroximately twice the efficiency of current generation coal fired power plants, thus leadin to a duction in greenhouse gas emissions. The amount of $\mathrm{CO}_{2}$ for storage/sequestration is so haked. Moreover, the exit gas is an almost pure $\mathrm{CO}_{2}$ stream, requiring little or gas se aration before compression for sequestration. Therefore, the energy and cost $\mathrm{p}$ ties $b$ capture the $\mathrm{CO}_{2}$ will also be significantly less than for other technologies. Furthermo a andant fuels such as coal, coke, tar, biomass and organic waste can be use Despite advantages, the technology is at an early stage of development requiring s iu to many omplex challenges related to materials degradation, fuel delivery, reaction kinet $\mathrm{s}$, sta fabrication and system design, before it can be considered for commercialization This paper, to $N$ ing a brief introduction to other fuel cells, reviews in detail the current staty of the rect carbon fuel cell technology, recent progress, technical challenges and discusses the futu the tec ology.

1.

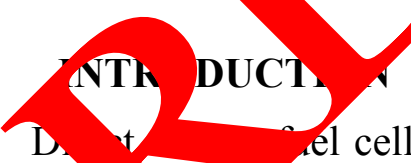

(DCFCs) are still at the very preliminary stage of development with only few a hors or industrial organizations reporting performance parameters on single cells or small stacks ch are somewhat similar to those obtained for gas fed fuel cell systems. Although a wide range of designs and concepts have been tested, there is currently no clear leader within the field with respect to optimal design or operating parameters. Even fundamental design parameters such as operating temperature are currently undecided.

DCFCs convert the chemical energy in a carbon fuel directly into electricity without the need for gasification. Fine (submicron) carbon particles in an electrochemical cell are electrochemically oxidized at high temperatures $\left(600-900{ }^{\circ} \mathrm{C}\right)$ with the overall fuel cell reaction being: $\mathrm{C}+\mathrm{O}_{2}=\mathrm{CO}_{2}$. The reactions in DCFC produce almost pure $\mathrm{CO}_{2}$, provided high purity carbon is used as the fuel, which can be contained in a concentrated stream and easily captured for downstream use or disposal avoiding the need for costly gas separation technologies [1]. The fuel and products are distinct separate phases (solid and gas), so their separation is easy and the fuel utilization can be almost 
$100 \%$ (typically $80-95 \%$ for other fuel cells). To avoid downstream processing of exit effluent, some processing of coal is required to remove impurities and to turn the fuel into submicron size particles. However, this processing is not as extensive or energy intensive as that required to gasify solid carbon fuels for use within traditional fuel cells or gas turbines. A variety of fuels including coal, coke, tar, biomass and organic waste can be used [2].

There are three basic types of direct carbon fuel cells: molten hydroxide; molten carbonate and oxygen ion conducting ceramic. In addition to the use of different electrolytes, there are further sub-categories of DCFCs which are differentiated from each other via the materials used within the anode, the design of the anode chamber and the method of fuel delivery to the electrode/electrolyte interface.

Overall effort in the development of DCFC technology has been relativelumall in comparison with other major fuel cell technologies [3]. The theoretical or nermon mic efficiency in DCFC is close to $100 \%$. Actual stack efficiencies are projected to $\quad 80 \%$ with btal system efficiencies estimated to be above $60 \%$ - almost twice those of current one on coal red plants and significantly higher than other fuel cell types. The projected cos, includin plant (BOP) is lower than most other fuel cell types with substantially er op ting cy due to the availability of cheap fuel sources [4].

The DCFC technology has many obvious benefits, howe er, it is an arly stage of development with considerable effort required to take it to the co ercializat stage [5]. Some major challenges that need to be resolved before commeraia zation clude: mode of solid fuel delivery to electrode electrolyte interface; fuel prosessm and quality requirements; understanding the electrochemical reaction kinetics and mechanism for can oxidation; corrosion of cell components especially where molten salts are ed either as the electrolyte or fuel carrier; lifetime; degradation rates and causes; improvement in terials $\mathrm{pe}$ formance and power densities; overall systems design; and technology up-scaling [6].

In this paper, a comprehensive review of technology and its current status has been given along with an overview of other fuel cell $t$

\section{BACKGROUND TO FUF $\angle \mathrm{CL}$ LS}

A fuel cell shown in Fig. 1s el coner device that converts chemical energy directly into electrical and heat en igy who cupplied with a fuel and an oxidant. It consists of an electrolyte, anode and hode. Tho ode and cathode are electronic conductors and the electrolyte conducts or $\mathrm{y}$ ion species The anode and cathode facilitate anodic and cathodic reactions respective yot the ano leetrolyte and cathode/electrolyte interfaces. Fuel is supplied to the anode and $g$ dant the cath de. The fuel oxidises at the anode by an anodic reaction that involves genera. of cectro s and either formation of ionic species which are transported through the electrolvte to th athode or formation of compounds by reaction between the fuel and the ionic species ans ted the electrolyte from the cathode to anode. The electrons generated in the ar ic re tion tray 1 through the outer electrical circuit to the cathode and are responsible for generat an the fuel cell. The cathodic reaction involves consumption of electrons, and either rea between oxygen and ionic species transported through the electrolyte or the formation of ygen anions which are transported through the electrolyte from the cathode to the anode. 


\subsection{Fuel cell efficiency.}

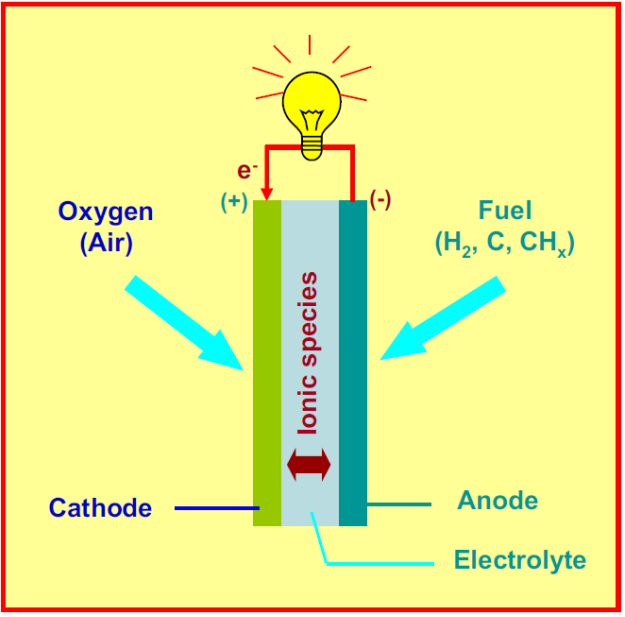

Fig. 1. The basic operating principle of a fuel cell.

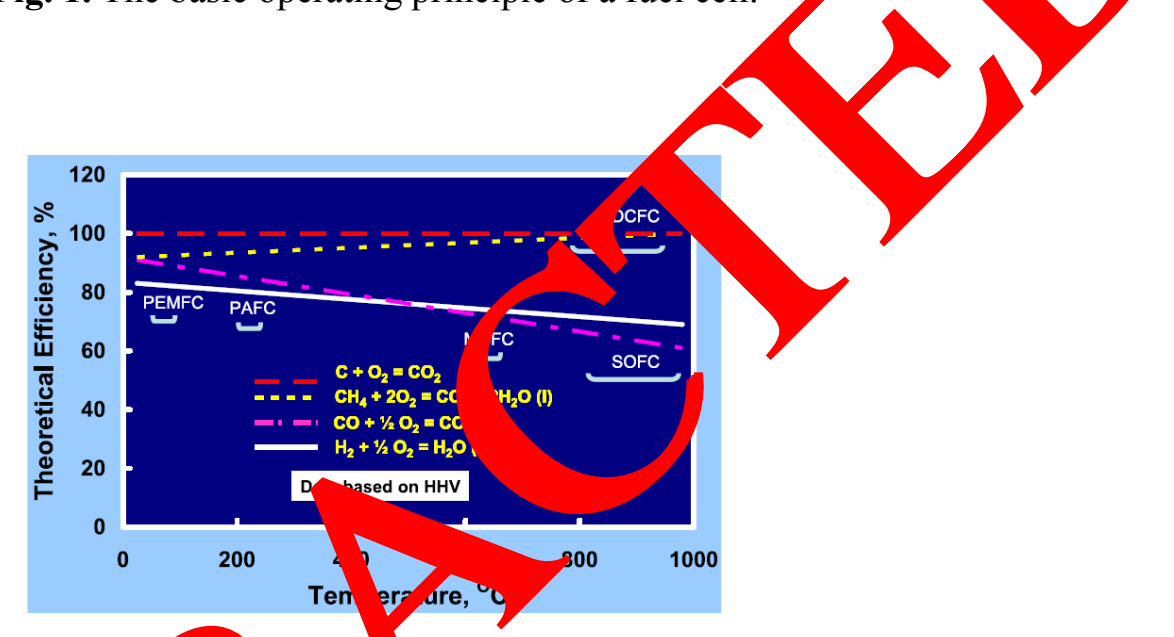

Fig. 2. The theoretical efficiency of deren hels calc ated from free energy of the fuel oxidation reaction as a function of temperature. Differ type of fuel cols and their operating temperature regime are also shown as an indication of their th tro narticular fuel.

The majority of $y$ eth used to onvert chemical energy into electrical energy rely on pressure and thermal ra lients cirst convert the chemical energy into kinetic energy which is then converted into ele a ical energy [ Aficiency of these systems is typically governed by the Carnot cycle. Fuel cell hower generate electricity via electrochemical reaction of the fuel and are thus not limited by th not cys [8]. The total amount of energy available to produce electricity is known as free oy a d is often referred to as the Gibbs free energy. The thermodynamic (maxim am) 1 effich $y\left(\phi F_{\text {th }}\right)$ of a fuel cell is defined as the ratio of free energy $(\Delta G)$ and enthar $\Delta t$ of the fuel oxidation reaction. Fig. 2 shows how the maximum or theoretical efficienc) vula vary with operating temperature of the fuel cell. 


\subsection{Different types of fuel cells.}

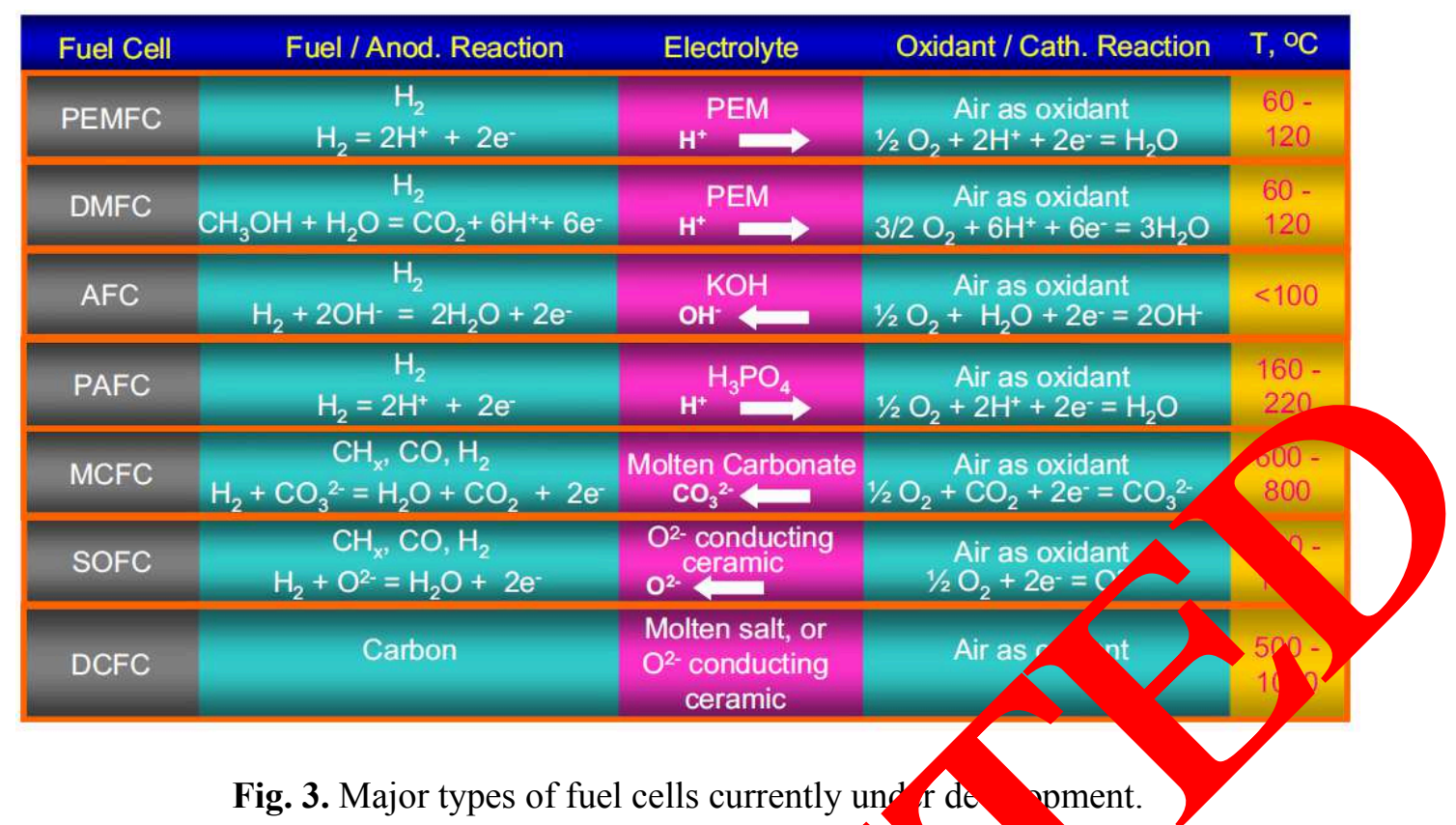

Fuel cells are generally named based on the type of erectrolyte a del used. Fig. 3 shows various types of fuel cells and their characteristics, $;$ e. fuel and oxiant, anodic and cathodic reactions, electrolytes and operating temperature range 9]. For deta led descriptions of other main fuel cell types see references [10].

\subsection{Fuels for fuel cells.}

A wide range of fuels have been suggeste fo, thy peration of fuel cells including ethanol, methanol, natural gas, kerosene, die aphtha, nydrogen and coal. Despite the large variety of fuels that have been suggested fo fuel ll syster at a cell level there is very little variation in what a fuel cell operates on 11 Ess Linl borohydride fuel cells, all c immerc fuel cens operate on pure hydrogen or a mixture of pure hydrogen and $\mathrm{CO}$. These ses are poed via external reforming, internal reforming or via partial oxidation of a w e ran comm,rcially available fuels [12].

\subsection{Fuel cell apr catic ns.}

The maje plic nons fuel cells are for distributed power generation either stand alone or integrated with ren ble en gy sources, transport and portable power etc. [13]. The application of fuel cell dep in on their operating characteristics, efficiency, cost, lifetime, fuel availa ity an process $\mathrm{g}$ requirements, requirements for the quality of heat in combined heat and power However, despite some major environmental advantages, most market segments a looking for high degree of reliability and costs which are competitive with existing technologies, 1 .

\section{DIRECT CARBON FUEL CELL}

The only difference between direct carbon fuel cell and others is that rather than being fed gas or liquid fuel streams, the anode chamber is supplied with a solid fuel that reacts directly at the electrode to form a gaseous exhaust product. Key features of a DCFC, as distinct from other fuel cells and power generation technologies are as follows [15]:

$>$ A DCFC operates at high temperatures $\left(500-900{ }^{\circ} \mathrm{C}\right)$ and converts the chemical energy in solid carbon directly into electricity through its direct electrochemical oxidation.

$>$ The fuel utilisation can be almost $100 \%$ as the fuel feed and product gases are distinct phases and thus can be easily separated. 
The theoretical efficiency is also high, around $100 \%$.

$>$ The by-product is pure $\mathrm{CO}_{2}$ requiring no gas separation and can be directly sequestered avoiding cost and efficiency penalties.

$>$ The solid fuel feed system for delivery of fuel to reaction sites can be quite complex compared to gaseous or liquid fuel fed fuel cell systems.

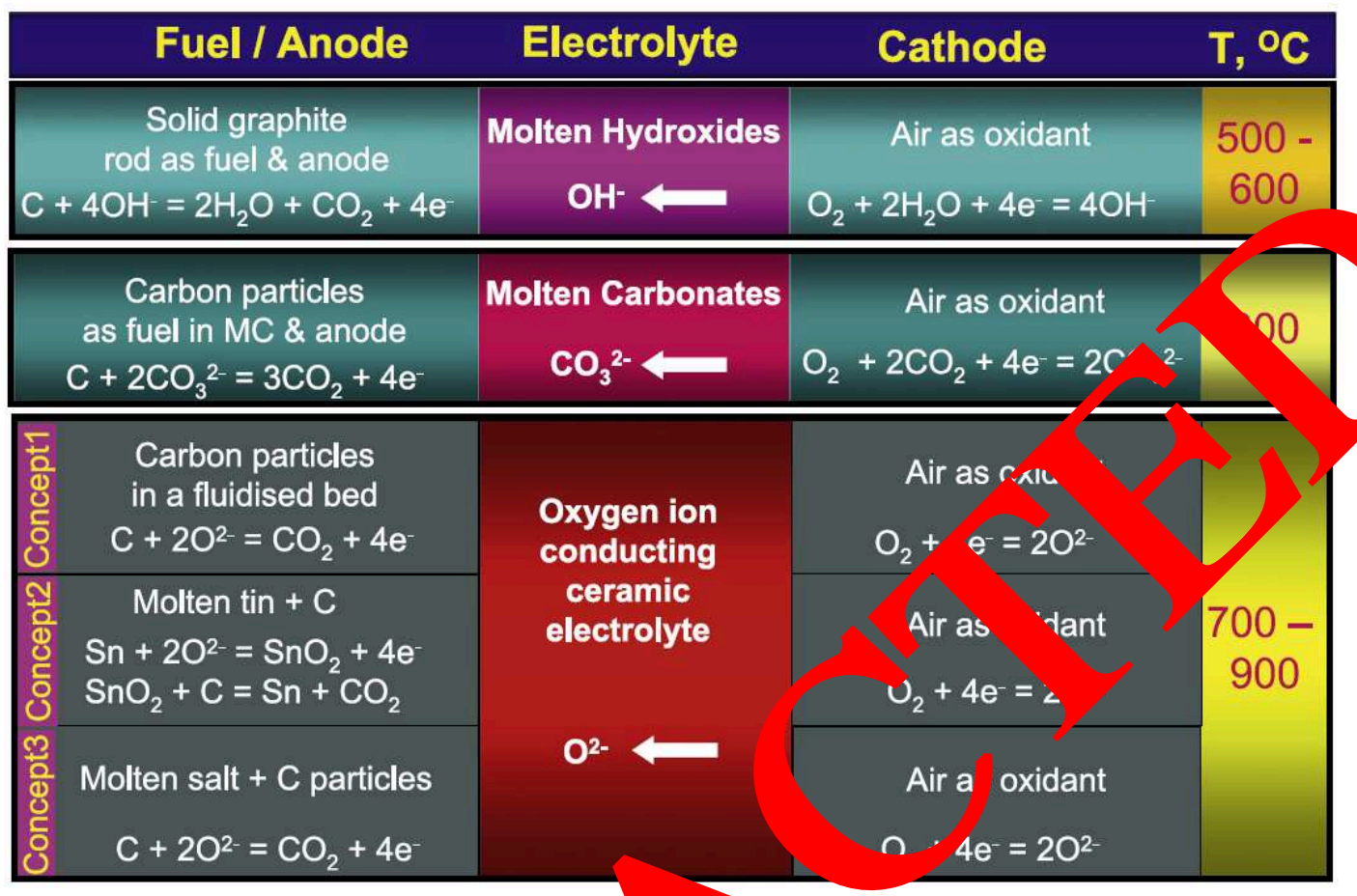

Fig. 4. Main types of direct carb $n$ fy 10 and fuel cell reactions.

There are three basic families or a ct carbo fuel cells under development, distinguished by the type of electrolyte used as $d$ ibed in Fig. 4 In addition to the use of different electrolytes, there are further sub-categoris ang in materials and design of the anode chamber. The various families and sy groups or cell are listed below:

$>$ Aqueous hydroxid $-\mathrm{to}$ erature $<2{ }^{\circ} \mathrm{C}$.

$>$ Molten hydroxire $(\mathrm{XOH}, \mathrm{QH})$ - temperature $500-600{ }^{\circ} \mathrm{C}$.

$>$ Molten carbo ate (Li, Na, K) imperature $750-800{ }^{\circ} \mathrm{C}$.

$>$ Oxygen is condy $y$ g geranic (doped zirconia or ceria) - temperature $500-1000{ }^{\circ} \mathrm{C}$ :

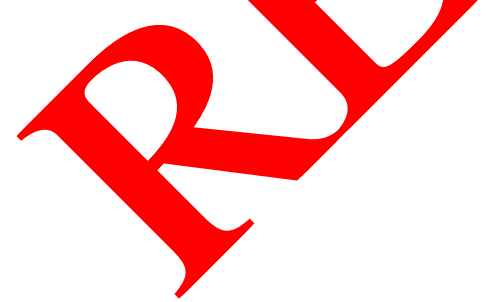




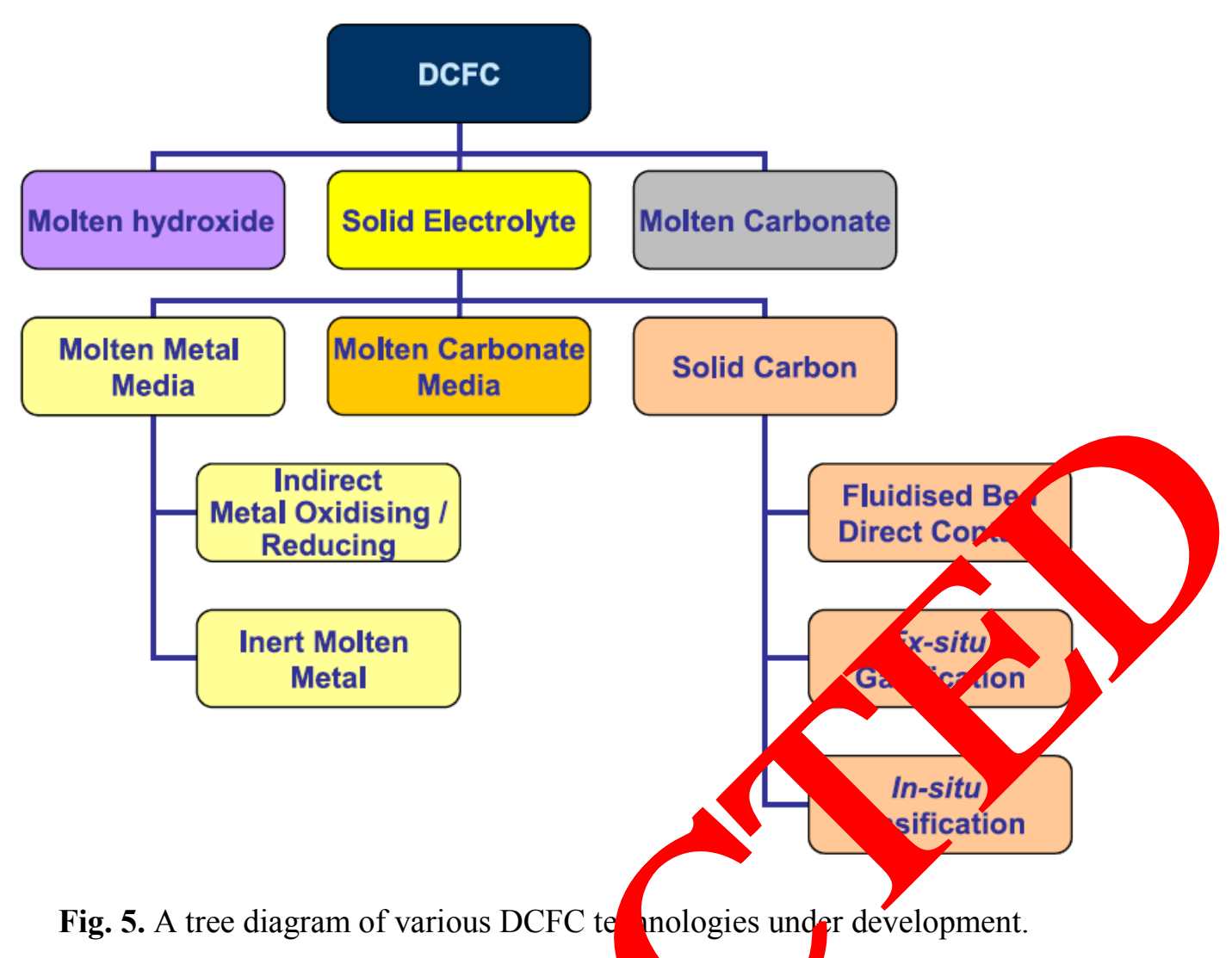

A tree diagram of various DCFCs is given in Fi to a dify various technologies under development. Many series of observations lead number or obvious operation rules that may be of use to the engineer looking to build a direct ca bort

$>$ Reduction in operating temperature redu $\%$ botb the thermodynamic driving force and kinetics of chemical reactions ${ }^{t}$ an $\mathrm{m} \mathrm{CO}$.

$>$ Continuous operation of a d ct can on fuel $\mathrm{M} / \mathrm{l}$ is advantageous as it avoids formation of CO within the anode.

$>$ Exposure of the carb fuel to $\mathrm{Q}_{2}$ in an unloaded fuel cell at the operating temperature should be minimize

\subsection{Aqueous hyd oxiue electrò eáchnology.}

DCFCs or rating t temperatures below $250{ }^{\circ} \mathrm{C}$ have been tested. These systems use an aqueous hydrox ectroly and thus must operate at greatly elevated pressures in order to maintain the-ectro as a rquid. Early work was carried out within autoclaves at $200{ }^{\circ} \mathrm{C}$ and 30 bar presure th raw $\mathrm{n}$ coal as the fuel [17]. The autoclave body was used as the anode with an in od sed as the cathode. The fuel, brown coal, was dispersed in an aqueous alkaline electroly tricsu als resulted in an OCV of $0.55 \mathrm{~V}$ which rapidly dropped to zero. Little information available on the reason for the rapid drop in performance with Howard suggesting that is was rele to reaction of the fuel with the cathode [18]. 


\subsection{Molten hydroxide electrolyte technology.}

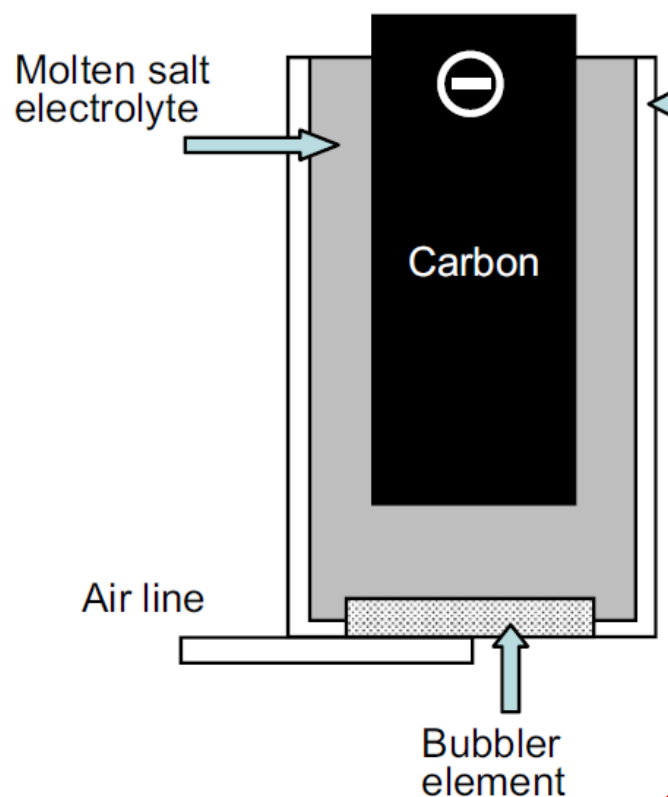

Fig. 6. A schematic drawing of a DCFC used by SARA i. most heir invertigations.

Generally this type of direct carbon fuel cell use molten hydroxid ( $\mathrm{NaOH}$ or $\mathrm{KOH})$ as the electrolyte which is contained within a metallic conta er which aløo acts as a cathode. A carbon rod made from graphite or coal derived carbon is dipp into the ectrolyte and used as both the fuel and anode of the cell. SARA has continued to develo teo nology with emphasis on solving problems and development and optimization 11/stack materials and designs. Fig. 9 shows a schematic view of the hydroxide based direct c rbor cll design used by $\mathrm{Xu}$ et al. in most of their investigations [19]. These cells use molten odium hydroxide as the electrolyte and a solid carbon rod as both the fuel and anc ae. e molte electrolyte is contained in a metallic container which serves as an air electrode 


\subsection{Molten carbonate electrolyte technology.}

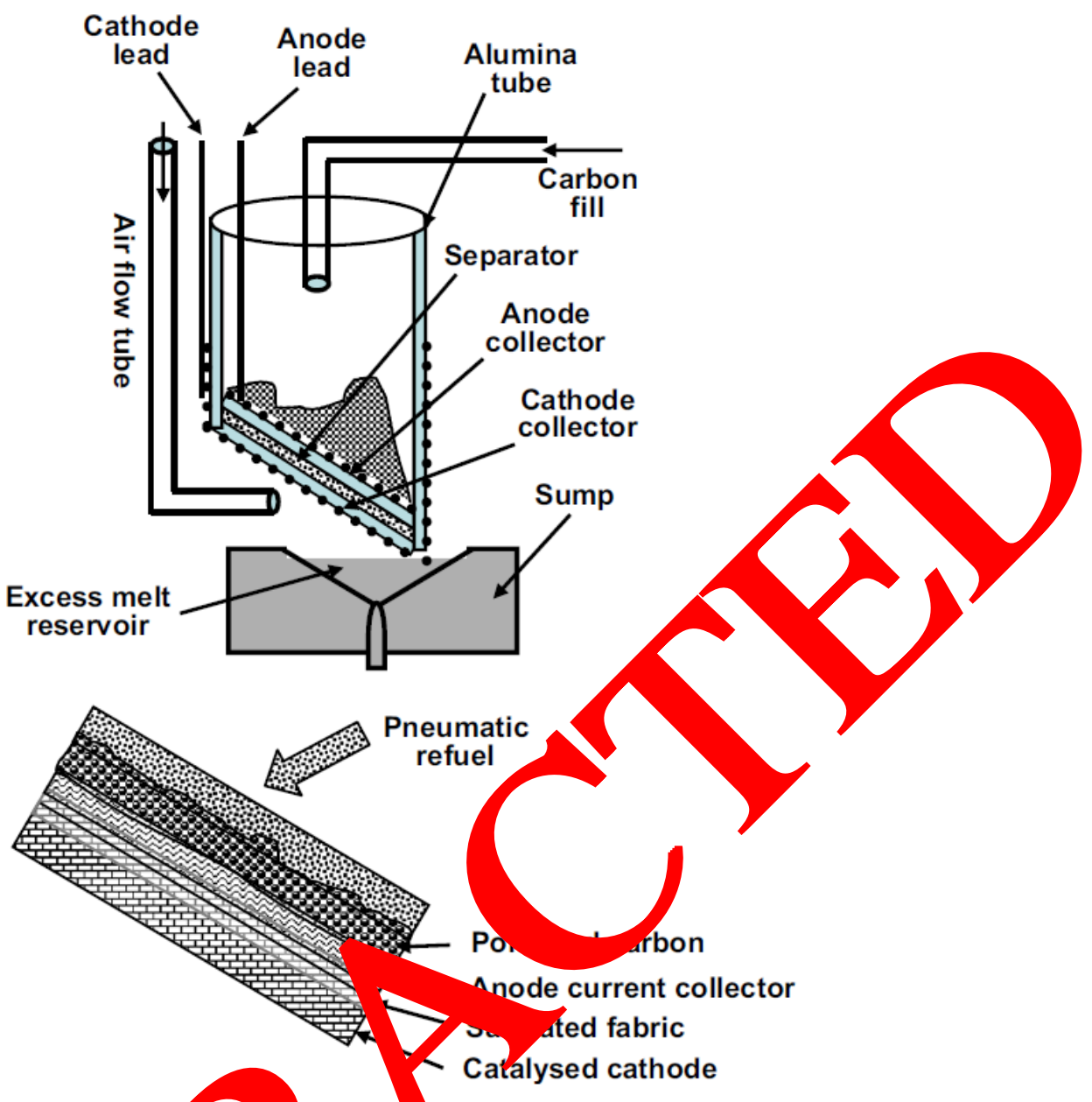

Fig. 7. A schematic dray a a a cell configuration of the tilted DCFC of LLNL.

Gas fed molten carbo the fuel ce re one of the most commercially mature types of fuel cell systems. Essentially the aire arbon ver on of the cell is similar to the gas fed molten carbonate fuel cell. Through ou ficatio to the system design it is proposed, and indeed it has been demonstrated at a mall scale, tha $1 \mathrm{~s}$ possible to operate a molten carbonate fuel cell system on solid carbon fu with ectric efriciency as high as $80 \%$ with near $100 \%$ fuel utilisation. Fig. 7 depicts one desis oposed $\mathrm{y} \mathrm{Li}$ et al. [20]. The carbon fuel in the form of fine particles is supplied with olter carbonate electrolyte. The unconventional tilted design allows excess molten electr yte to by ained and for the cell to be continually refuelled with a carbonate slurry. Other on maces closely resemble the Jacques design have also been tested [21]. 


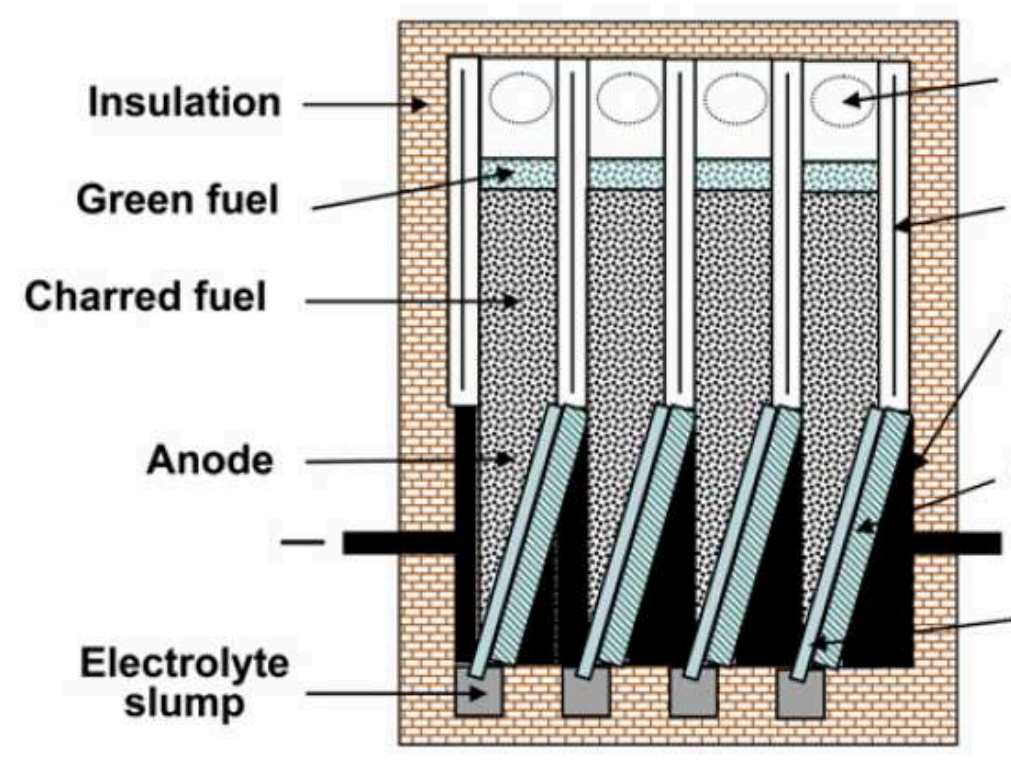

Pneumatic fill tubes

Mid-BTU gas or $\mathrm{CO}_{2}$

Heat exchanger

Bipolar plate

Air distribution

Fig. 8. Design of LLNL's self-feeding cell that is refuelled pneumat ally and cleaned coal.

Kacprzak et al. [21] have also designed a self-feedin that is pheumatically and incorporates internal pyrolysis of the coal as shown in $Y \mathrm{~g}$. 8. The pyroly /s of coal would produce hydrogen, and low molecular weight hydrocarbons $d$ a non-ag olomerating char, and that is reactive and sufficiently conductive, for use as a fuel DCFC. The team at LLNL reported that they intend to test a 75-150 W, 5-cell self-feeding bipolar are turbostratic carbon as the fuel. However the technology was licensed to mined Energy and there have been no further reports on the progress of the work.

\subsection{Oxygen ion conducting electronto chnolo}

This type of direct

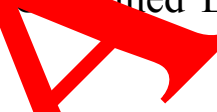

Sepa

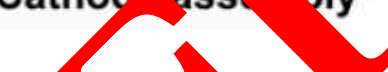

2

pyrolysis of

trolyte similar to that in the solid o fuel cell (SOFC) [22]. There are three sub-categories of DCFCs that use an oxy on conductin ceramic as the solid electrolyte. These differ only in the anode chamber design a d are ussed as following.

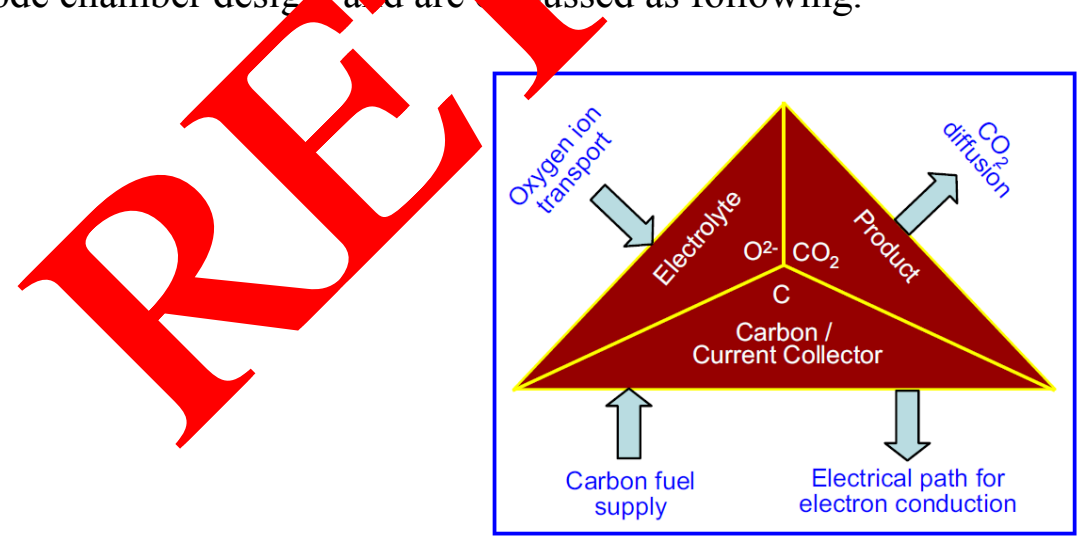

Fig. 9. Schematic diagram of a triple phase boundary required for a DCFC using a solid oxygen ion conductor electrolyte and particulate carbon as fuel.

Fuel as solid carbon or in fluidized bed. It is possible for the fuel to react within a solid oxide fuel cell anode via a number of different reaction paths. Which reaction path dominates is largely dependent on the fuel composition and the anode design [23]. A schematic of the triple phase boundary is shown in Fig. 9. Direct electrochemical reaction of carbon at carbon/anode or 
carbon/anode/electrolyte interface in this way may result in lower power being generated from the cell due to the small number of available reaction sites when compared to conventional porous SOFC anodes involving gaseous fuels [24].

Overall DCFCs that operate directly with carbon within the anode chamber and which have been evaluated by various authors, can be further sub-divided into four families [25]:

$>$ Vapor deposited systems - hydrocarbon fuels are decomposed within the anode chamber, directly depositing carbon over a large area within the anode.

$>$ Consumable anodes pressed against the electrolyte - carbon is pressed directly to the electrolyte.

$>$ Carbon placed within the anode chamber but not necessarily in constant direct contact with the anode or the electrolyte and includes systems with fluidized or packed beds and cystems where the fuel may simply be within the anode chamber either in direct co act or mall distance from the anode.

$>$ Use of an integrated external gasification - carbon gasified external to thefuel stack.

Ju et al. [26] employed a two compartment carbon fuel cell arrangen ent as sho in F. 10 for their investigations on electrochemical conversion of carbon to lectric energ at high temperatures. The set-up consisted of a tubular yttria-stabilised zircop solid e ctrolyte cell placed in one section and carbon pellets placed in another section of a quar be. ratinum paste was used to make porous platinum electrodes inside and outsid 1 YSZ tube. MSZ tube was placed such that the open end of the tube was outside the quin tube supplyng air to the inside of the YSZ tubular cell.

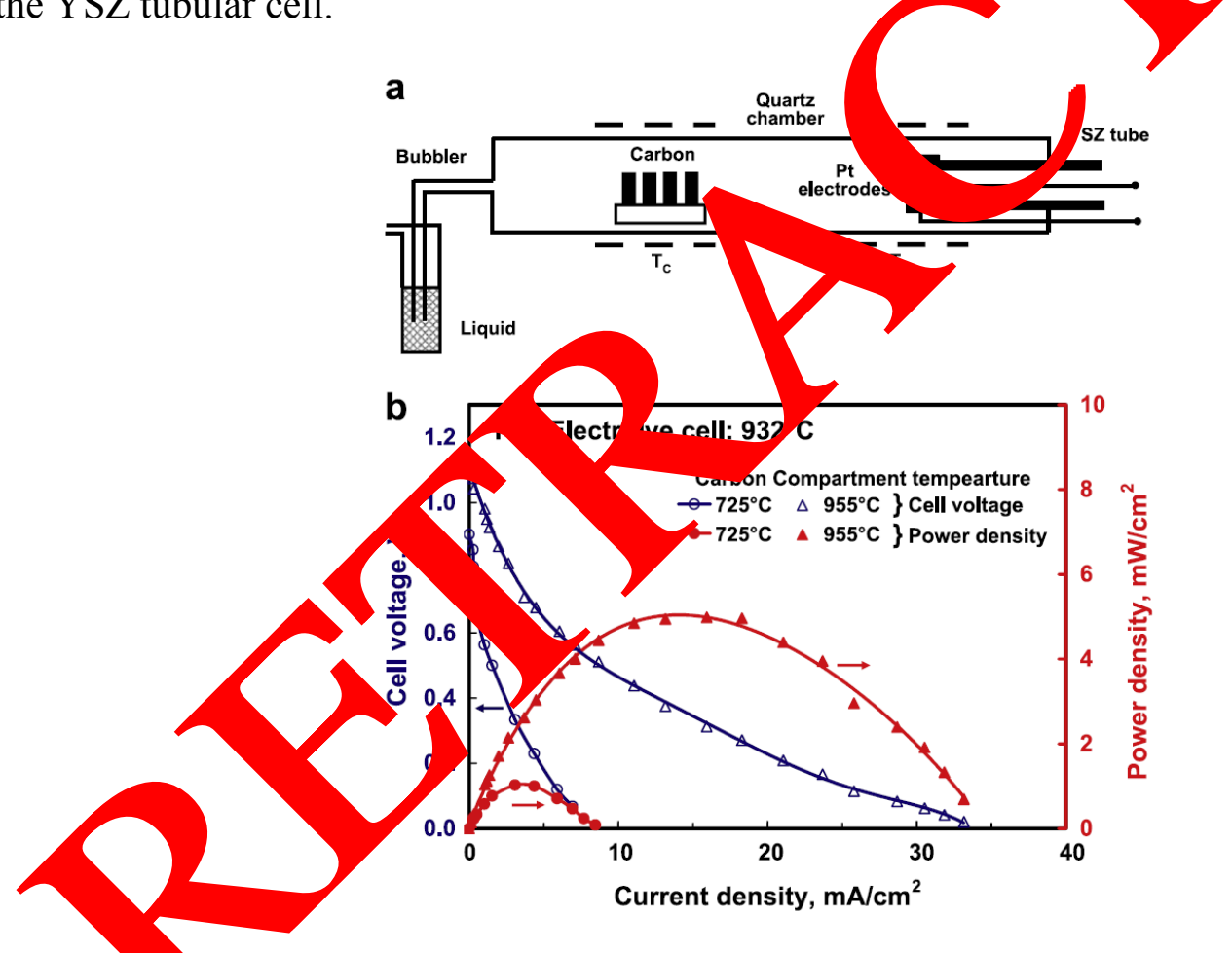

Fig. 10. (a) bematic drawing of a two compartment DCFC set-up employed by Gür and Huggins for their investigat ons. (b) Voltage - current density and power density - current density characteristics of the cell under resistive load.

Fuel in molten metal. Molten metals have been tested as fuel cell electrodes on many occasions in early solid oxide fuel cells. These metals can be inert which transport ionic species to and from the electrolyte in solution or reactive which oxidise at the electrode surface and are then reduced by the fuel [27]. 


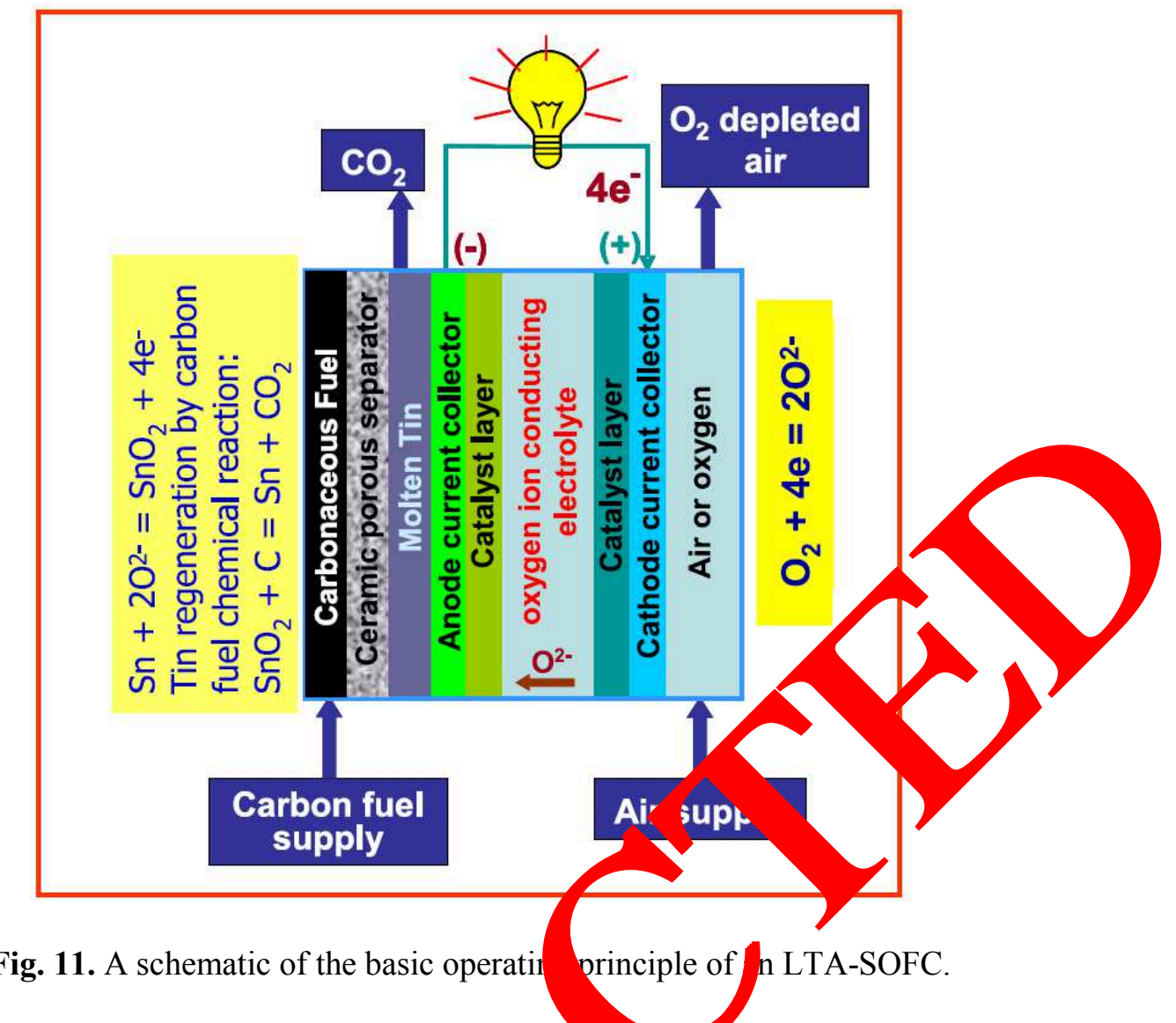

Fig. 11 shows the basic operating princip of Cell ${ }^{1}$ quid tin anode based direct carbon fuel cell. This type of device can act as a prit an cecondary battery or a fuel cell. As with a battery, the CellTech cell can operate for signit an an its of time with no fuel being added to the system [28]. Although literature rem the $\mathrm{u}$ of molten metals such as $\mathrm{Sb}, \mathrm{Pb}, \mathrm{In}, \mathrm{Sn}$ and $\mathrm{Bi}$ in high temperature batteries, howe er, $\mathrm{c}$ iplete o idation of the liquid metal does not occur due to the formation of an insulating an lay hetween the electrolyte and the remaining liquid metal, the exception being bismuth and Is mos- inely due to the high ionic conductivity of bismuth oxide. The low oxidation antial of $b$ uth makes it unlikely that a liquid bismuth anode would be of practical use in eit er a cell or a sattery.

Fuel in molte arbona. This technology combines a solid oxide fuel cell with a molten carbonate fuel cely and is one of th nost recent design concepts under development [29]. Although there are some iation the design, essentially this type of system consists of a solid oxide fuel cell in which the $a$ e has b in flooded with a slurry of molten carbonate and carbon fuel. Fig. 12 depicts th ic prin le $/$ the technology. This type of fuel cell system avoids the need for $\mathrm{CO}_{2}$ circula on an protects ne cathode from molten carbonate, allowing the use of advanced cathode compos a developed for SOFCs. It also avoids cathode flooding and corrosion issues associated the closely related molten carbonate direct carbon fuel cell. 


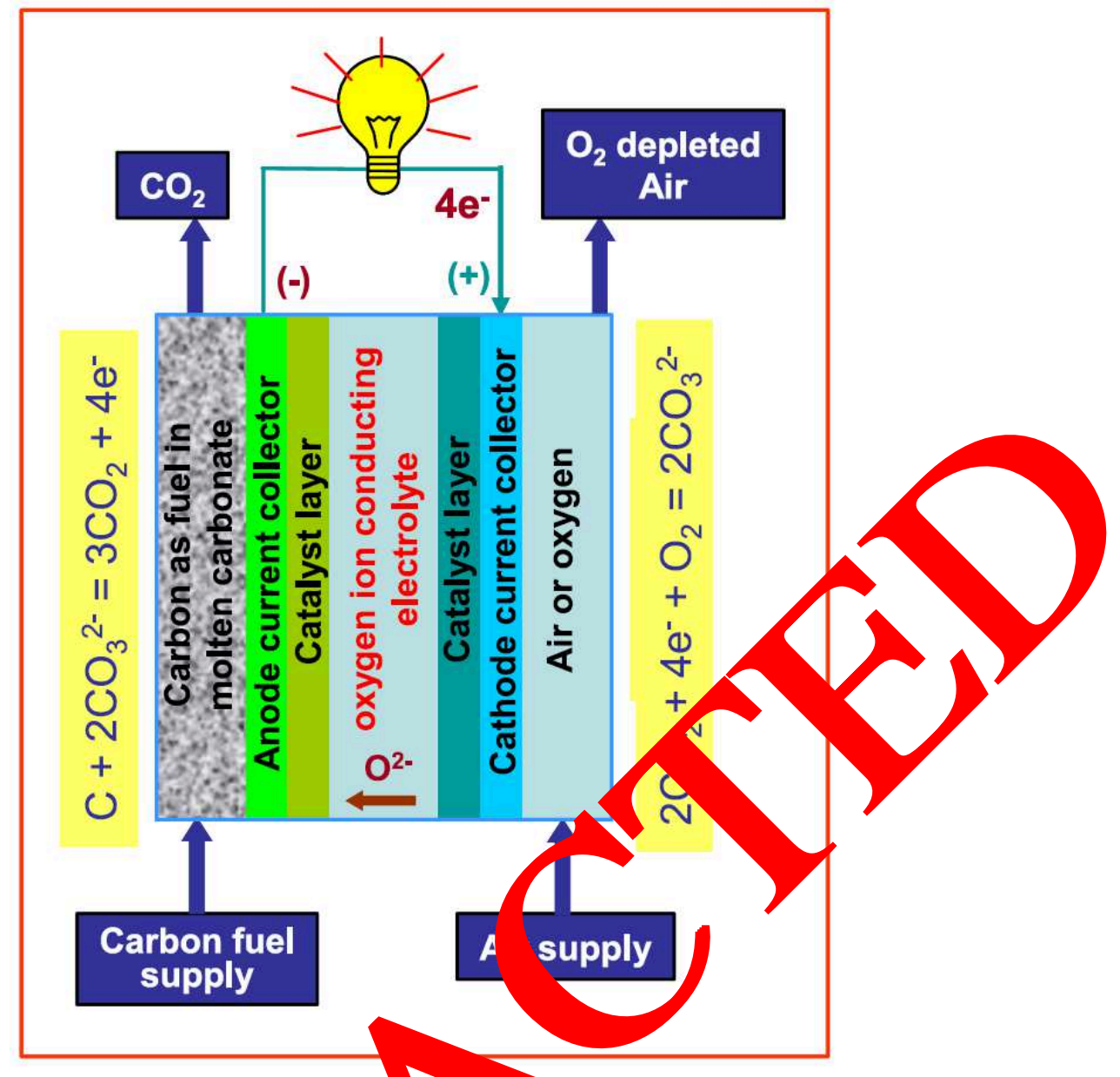

Fig. 12. A schematic of the basic operating principle $\mathrm{S} D \mathrm{DCF} y$ based on carbon fuel mixed with molten salt on the anode side and oxygen ion conduo lectroly

Fig. 13 shows a schematifa. ing cell DCFC construction proposed by Lee et al. [30] from SRI International $1 \mathrm{~m}$ ce mploys a cathode supported tubular cell geometry. Air is supplied via a concentric/ to the cat $/$ consisting of metal mesh or coil as a current collector and lanthanum strontiu ma. ate (LSM) as the catalyst layer. The electrolyte is yttria-stabilised zirconia (YSZ). The cylating tep salt mixed with fuel particles (more than $30 \%$ by volume) is supplied to the ar de si e of the ely drolyte which has an anode current collector. The anode current collector is a sio cosis ant metal/alloy coil or a mesh. Li et al. [31] have achieved power densities of up to $\mathrm{mW} / \mathrm{cn}$ using acetylene black as the fuel. The operating performance of this design y as o test an real fuels such as biomass, coal, tar and mixed plastic waste. Power densit achi ed with rese fuels were $70,110,80$ and $40 \mathrm{~mW} / \mathrm{cm}^{2}$ respectively. 


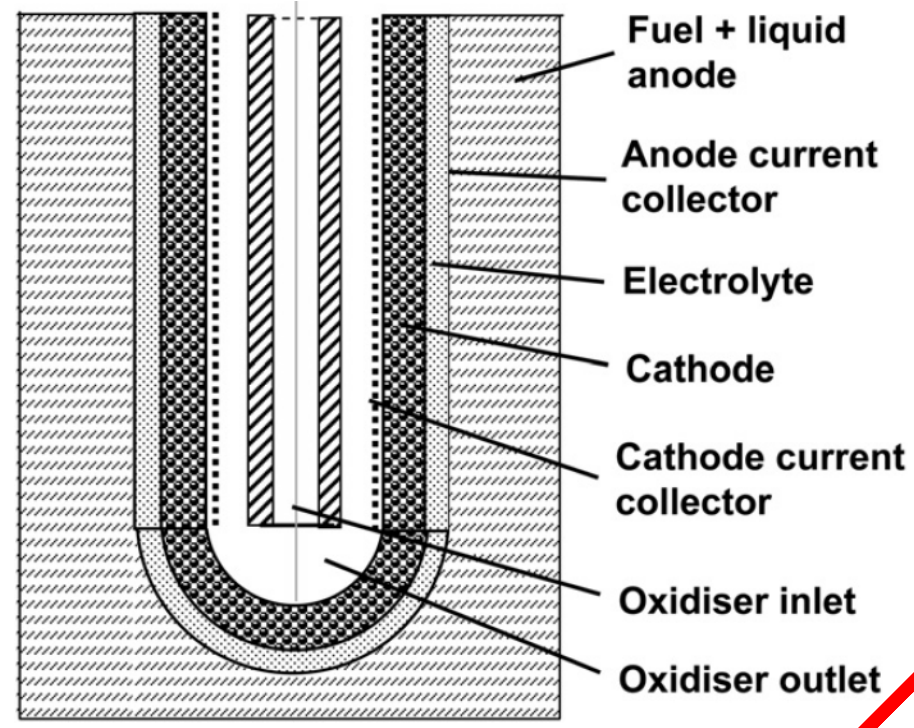

Fig. 13. A schematic of the basic operating principle of a DCFC based on co on thixed $\mathrm{w}$ molten salt on the anode side and oxygen ion conducting electrolyte.

SRI International had been quite active for this type of th hnolo and has tested solid carbon fuels mixed with salt powders [32]. Fig. 14 shows an SR tiple tub DCFC stack prototype. As with most DCFC designs, the formation of $\mathrm{CO}$ at hi n temperature is a issue. One strategy that has been adopted to try and eliminate CO formation vi he reverse Poudouard reaction is to reduce the operating temperature of the cell. This has lead a nu er of inve tigators to trial a wide range of cell concepts and designs that may offer lower temperatu

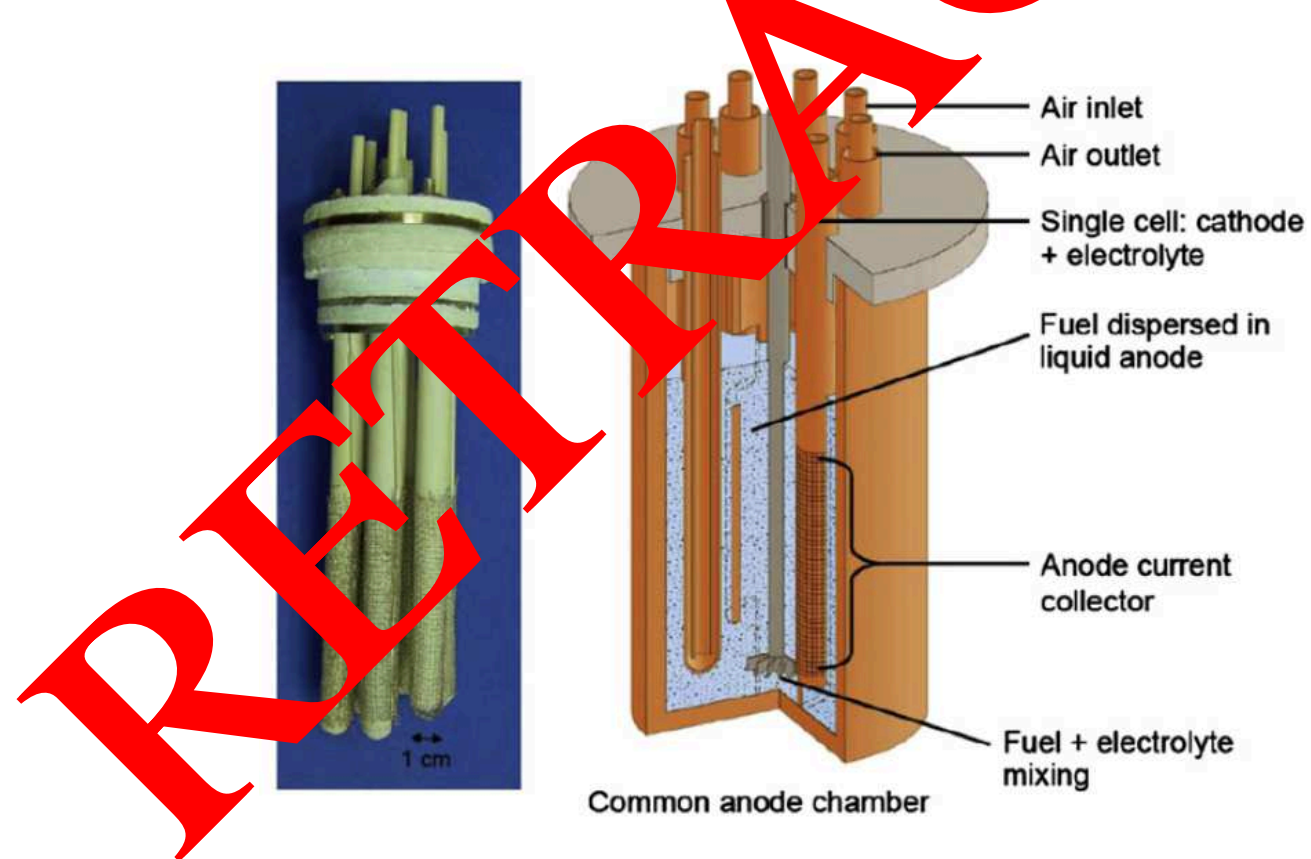

Fig. 14. Cutaway drawing of an SRI designed eight cell stack with eight YSZ electrolyte tubes inserted into a common anode (carbon fuel in molten salt) chamber.

\subsection{Fuels for DCFC.}

A DCFC utilizes solid carbon as a fuel, the structural and chemical characteristics of which play a vital role in performance of the fuel cell. In particular when coal is used as the fuel, its characteristics and properties can vary greatly depending on the source and pre-treatment. Direct 
carbon fuel cells have been operated on a wide range of fuels including coal, liquid hydrocarbon fuels, biomass and organic waste. Some of these fuels have been used directly within the fuel cell with very little pre-treatment whilst others have been heavily processed and purified to produce a fuel that is almost pure carbon [34].

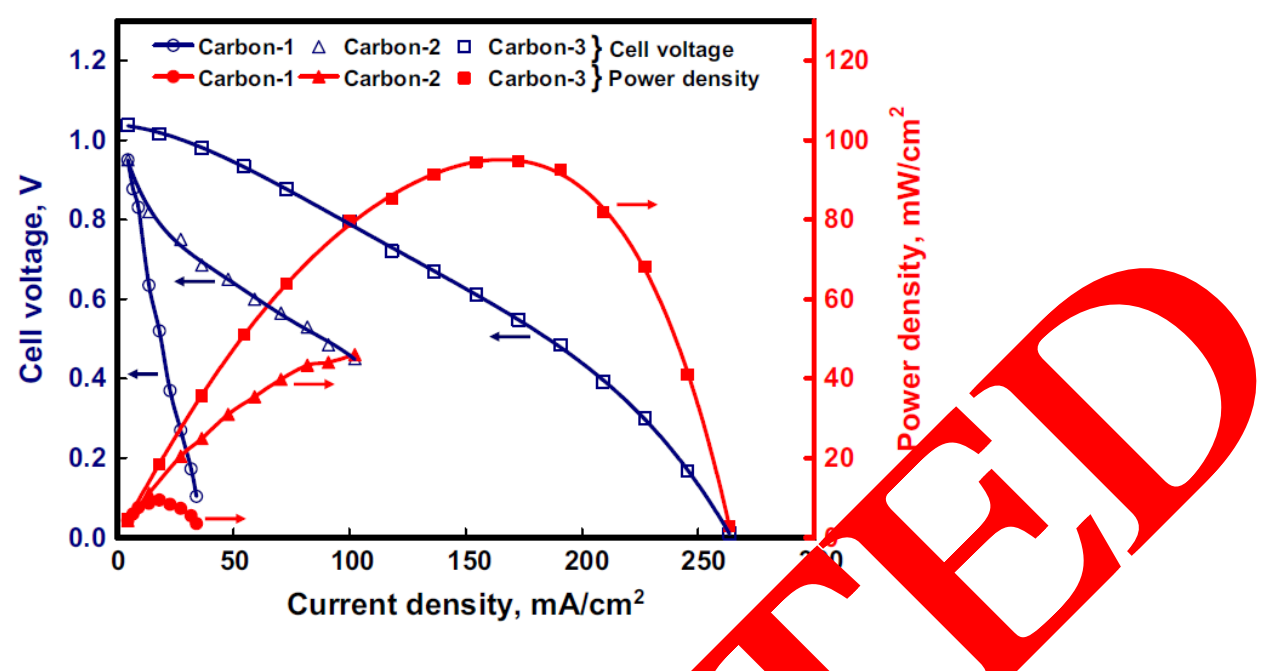

Fig. 15. Voltage - current density and power density - current dens y cha eristics on a molten carbonate electrolyte based DCFC at $850{ }^{\circ} \mathrm{C}$, operated on three carbon $b^{1}$ made b, vrolysis, but with different structure on a nanometer scale.

Dudek et al. [35] have reported an investigation various ty pes of carbon blacks and have tried to correlate their electrochemical reactivity in a mo carbor ate electrolyte based DCFC with micro- and nanostructures of carbons, which sh in Fig. Is. Ine observations on three samples of carbon black showed a large variation in peak bwo sities. It was suggested that this variation was largely due to a significant differences in $\mathrm{mi} r \mathrm{r}$ and $\mathrm{y}$ anostructures of the three types of carbon black samples. XRD measurements ed that 11 samples of carbon had much larger spacing between layers of carbon atome and ly a sn 1 area of crystallinity when compared with graphite.

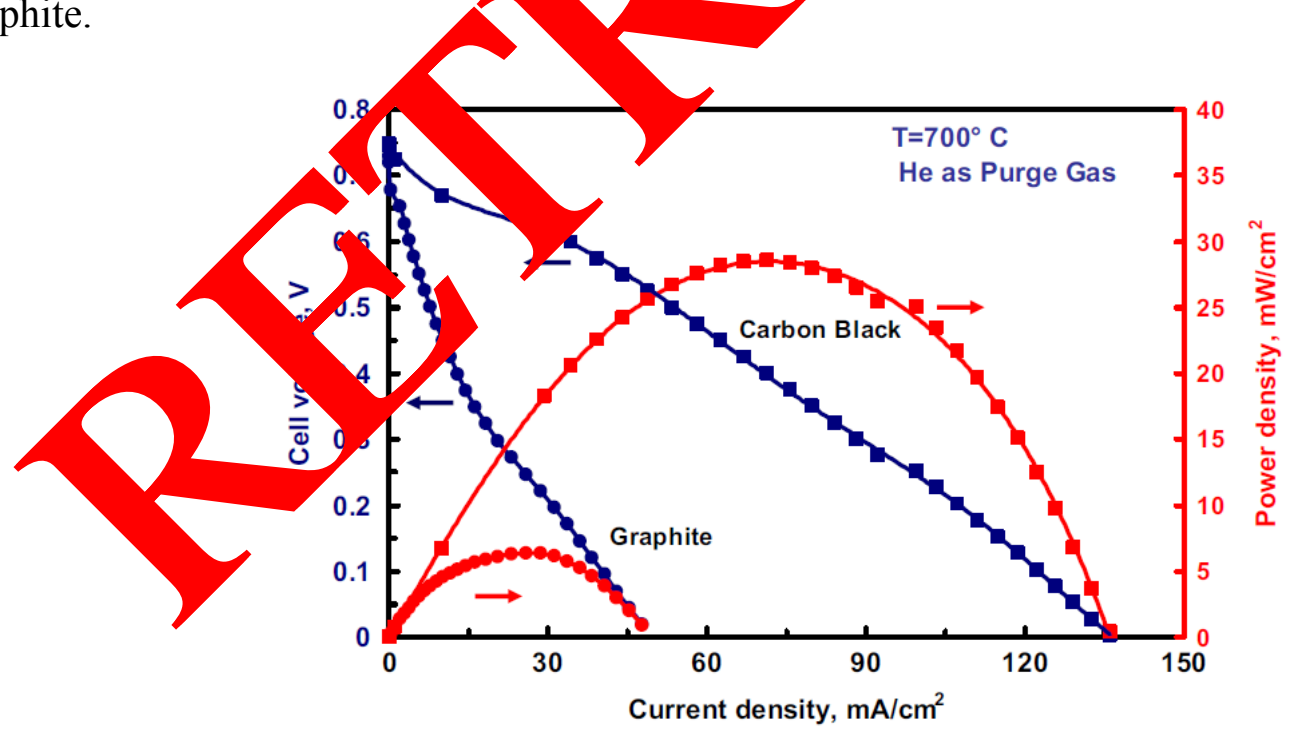

Fig. 16. Voltage - current density and power density - current density characteristics of a solid electrolyte based DCFC at $700{ }^{\circ} \mathrm{C}$, operated on carbon black and graphite as fuels, and helium as a purge gas.

Kim et al. [36] have shown that for a solid electrolyte based DCFC, somewhat similar behavior is observed. They found that amorphous carbon fuel was more reactive electrochemically and produced higher power density in comparison with micronized graphitic fuel when tested under identical fuel cell operating conditions, which shows in Fig. 16. It should be noted that most coal 
derived carbons are generally amorphous and have disordered structure. It has been known that surface functional groups of heteroatoms such as oxides and nitrates play an important role in physical and chemical properties of carbon. Properties of carbon such as electrical properties, wettability, zeta potential, catalytic activity and adsorption capability can all be altered by appropriate surface treatments such as nitradation and oxidation. In the carbon electrode materials in Li-ion batteries, the presence of oxygen groups on the surface results in increased capacitance and wettability by the electrolyte. The surface chemistry is considered to play a vital role in such applications and hence the modification of surface chemistry by various treatments is seen as a promising way for improved performance of carbon materials in catalysis, adsorbent and energy storage applications. In the case of DCFC as well, the modification of the surface functional group or surface activation of carbon fuel is thought to influence the performance [37].

There are also many factors that require further investigation [38]. The oxidalion on bon appears to be the rate limiting step in all direct carbon fuel cell designs with except of systems based on gasification and, potentially, systems with molten metal apodes. erefore it is essential to gain a good understanding of the carbon oxidation mechanis $/ \mathrm{S}$ within $\mathrm{fu} / \mathrm{A}$ cell design in order to improve performance and select appropriate fuels ar establ fuel ocessing requirements. Although, this work has already commenced, results s s omewh fragmented and systematic studies on the impact of various fuel properties oy a wide oe $\sigma^{f}$ direct carbon fuel cell operating conditions are required [39]. Initial data suge es at the folly $\mathrm{mg}$ broad factors are likely to be critical to the fuel cell performance:

$>$ Carbon structure and the degree of crystallinity of ca

$>$ Wettability of carbon fuel in the case of molten m lia based DCFC.)

$>$ Electrical conductivity of carbon.

$>$ Particle size, pore size distribution and surface are

$>$ Surface functional groups (nature and de of funo

$>$ Type of impurities and their concentration

If a detailed understanding of these facto cedru gained and results used to design and develop low cost fuel pre-processing tachnique to produce a range of high performance fuels specifically tailored for the type of a ect car on fuel cell, it is likely that overall system performance would be greatly proy d. This would also accelerate the development and commercialization of direct

\section{COMPETING TE NOLOQ TES, SIGNIFICANT ISSUES AND FUTURE DIRECTION FOR GIC}

DCFCs $\rho^{f}$ er mo v advantages over other types of fuel cells and power generation technologies inc ing the hi het efficiency approaching 70\%, almost sequestration ready $\mathrm{CO}_{2}$ without the aubstan extra cost and energy losses associated with its capture and the use of low cost fue $\mathrm{Fu}_{\text {. }}$ Cell en offer fuel cell systems based on a molten carbonate electrolyte operating on $\mathrm{n} \quad \mathrm{ga}$ with an electrical efficiency of $47 \%$, which can be scaled from $300 \mathrm{~kW}$ up to 50 MW. Th sysum could be operated on cleaned gasified solid fuels such as gasified coal. System modelling Eom et al. [40] have suggested that an integrated MCFC, steam turbine and autothermal g offication system could attain an efficiency of around $47 \%$. This is similar to the overall system efficiency of a state of the art IGCC power plant which is typically taken to be $45 \%$, however, with the clear advantage of a fuel cell/gasifier system could be designed to produce an almost pure $\mathrm{CO}_{2}$ exhaust stream which can be easily captured for sequestration. In the case for advanced IGCC plants, for capture of over $90 \%$ of the $\mathrm{CO}_{2}$, the overall efficiency would fall to around $40 \%$.

As part of the SECA program, there has been significant effort in the USA, developing an integrated coal gasification solid oxide fuel cell system [41]. A number of detailed system modelling studies have shown that, in principle, it is possible to achieve an overall system efficiency of over $45 \%$ for an atmospheric pressure coal gasification fuel cell system and around $60 \%$ for a pressurized system both without $\mathrm{CO}_{2}$ capture [42]. With $\mathrm{CO}_{2}$ capture the efficiency 
would drop to 43 and $57 \%$ respectively for atmospheric and pressurized systems. In contrast, the efficiency of a molten carbonate DCFC system has been predicted to be over $70 \%$ with $\mathrm{CO}_{2}$ being the main product gas which can be easily captured for storage [43]. A system of this type would become cost competitive with IGCC and NGCC plants with $\mathrm{CO}_{2}$ sequestration at around US $\$ 2000 / \mathrm{kW}$ installed cost [44]. However, as discussed before DCFC systems are at an early stage of development compared to the conventional SOFC systems used in the SECA program and there are still a significant number of technical materials stability and fuel reactivity challenges that need to be overcome before solid carbon can be directly used in a commercial fuel cell.

The development of direct carbon fuel cells to commercialization stage is largely prohibited by the following key technical issues [45]:

$>$ Poor power densities.

$>$ High degradation rates - corrosion of cell components.

$>$ Fuel feed system - getting the fuel to the anode.

$>$ Up-scaling of the technology to $\mathrm{kW}$ and larger size systems

$>$ Establishing fuel processing requirements to produce low cost fuel.

There is no one area within the overall study field, where a conce and ordin d effort from the development sector would result in a breakthrough th commercialization of this technology. A number of technology challeng eed $/ 0$ be tackled simultaneously [46]. The major limit to DCFC performance s ted to th ate of the fuel, because the fuel is solid it cannot diffuse to the active sites w thin a rous electrode this greatly reduces the number of accessible active sites where g'ammal oxida $/$ can occur [47]. This combined with the sensitivity of conventional anodes (Y -YSZ) to poisoni/g and carbon deposition, makes conventional fuel cell designs and materials im actical [48]. The use of molten metal's and salts that flow into the fuel cell show promise as these vtems co? the surface of the fuel greatly increasing the surface area available for reaction Howevo. of molten materials also greatly increases the degradation of any system either mical attack on other system components, as with molten salts, or through rapid reaction wit fue ritities as with molten metals which will alloy with even small quantities of matal withi the fuel [49]. Gasification of the carbon is an appealing option as it greatly increases power density by allowing the fuel to fully access the anode, allows for the use of far or u derstood traditional' SOFC materials and eliminates the

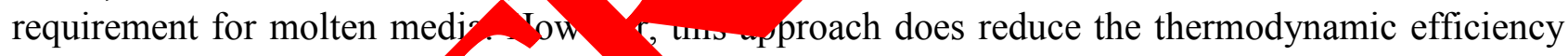
and, if a system of higher ciency tha standard thermal power plant is to be developed, greatly increases system compl aity 7 . Directl introducing the carbon to the anode chamber as opposed to the thermal integr to of a ternal gasifier may reduce the system complexity and improve efficiency by alloring some dired xidation of carbon in contact with the anode, however, it will increase the $\mathrm{ma}$ ial rea vity issues and increase fuel processing requirements.

The other areas equiring effort to improve the DCFC performance and take the technolog omm alizan stage are: development of anode materials that can extend TPBs to increa solic fuel rea ve sites for example the use of mixed ion conductors or partly utilize gaseou. required of fuel processing that maximizes its reactivity at the fuel/electrode or electrode/elo 1/yte interface and reduce anode degradation and prolong fuel cell life [52]; development of electrode supported cell designs preferably cathode supported to minimize the electrolyte and anode thickness to reduce resistive losses across electrolyte and enhance fuel transport/diffusion through anode [53]; and development of cell materials for low temperature operation to minimize materials degradation issues [54]. General programs looking generically at 'performance' or 'degradation' across the whole field, rather than focusing on one or two specific system concepts, are unlikely to result in the driving of this technology towards a commercial product.

Despite the early stage of most development programs, there are already examples of single lab scale fuel cells of various designs that offer sufficient performance [55]. What is required is significant increase in the scale of fuel cells trialed both in terms of the size of the fuel cells tested 
and the length of time of each test to demonstrate sustained power densities and low degradation rates [56]. If direct carbon fuel cells are to follow a similar commercialization path as of other fuel cell types such as PEM, MCFC, SOFC or PAFC, the solutions found during the development and long term testing of a system at roughly $\mathrm{kW}$ scale will greatly catalyze the commercialization of the technology [57]. Stack, system and flow sheet modelling also need to be performed to address issues such as thermal and mechanical stresses, energy and mass balance, fuel utilization, system efficiencies [58].

\section{CONCLUSION}

There are currently five distinct types of DCFCs under development by various groups globally. These include one based on molten hydroxide electrolyte, one based on me unir electrolyte and three based on solid oxide electrolytes. For the three based on solid ide electrolytes, there are different methods of fuel delivery. For each type of Du there a number of design variations, different technical issues and performance outc mus. In tition here is the complication whether DCFC involves total direct carbon oxidatic or $p_{s}$ tial $d_{h}$ carbon oxidation in electrochemical reactions or indirect conversion, first to $\mathrm{Co} d \mathrm{~d}$ en trochemical reaction of $\mathrm{CO}$ in a conventional SOFC. There are significant im sioution or ove all electrical efficiency depending on the reaction mechanism.

The international effort towards developing DCFC ech oy is ratively small in comparison to MCFC, SOFC and PEMFC technologies wit 1 ny a fer ajor key players. Most of the $\mathrm{R} \& \mathrm{D}$ is performed at study organizations. A part rom SARA, the is no other major well established company working in the area. A numb of small companies have been formed exclusively to study, develop and commercialize the GFC techn logy. Most groups are testing small cells or stacks over short time periods. Typical po densi es achieved from DCFCs are in the $5-150 \mathrm{~mW} / \mathrm{cm}^{2}$ range, although somewh rer valus have been reported especially for systems operating on Boudouard gasification of arbe

There are very clear advantages of the D ve tec nology - high projected electric system efficiencies of about $70 \%$, almost reduct $n$ in emission of greenhouse gases and fuel consumption compared to current al fil d power rants thus substantially reducing the amount of $\mathrm{CO}_{2}$ for sequestration and ex na reserves, near $100 \%$ fuel utilization, $\mathrm{CO}_{2}$ produced is in pure form thy no gas s ration required leading to cost and energy savings and low operating costs. For cop a nal coal thermal power plants, about $20-25 \%$ of the power generated is lost in pos comb ion capture of $\mathrm{CO}_{2}$. All these factors point to a favorable power generation option y itm a direct o fuel cell. However, at the same time, there are substantial technical challer res in arms of d-livery of solid fuel to the electrode/electrolyte interface, long term effect on wa impu ties in the carbon based fuels, technology scale-up, corrosion of components due to her op rating temperatures, lifetime and degradation. Thus, a substantial R \& $\mathrm{D}$ effort is in ired. $\mathrm{h}$ oped that the integration of real world fuels at an early stage of system devel ent rogram y ill reduce overall R \& D costs, by reducing the overall development time and proa a syom that will be more applicable to a wider range of established markets avoiding the need iv arge investment in infrastructure. Due to the modular nature of fuel cells this technology on developed, DCFCs would be suitable for a wide range of applications from small domestic kilowatt systems to large centralized multi-megawatt facilities. 


\section{References}

[1] Cooper J.F., Selman J.R., Analysis of the carbon anode in direct carbon conversion fuel cells. International Journal of Hydrogen Energy 37(24) (2012) 19319-19328.

[2] Elleuch A., Boussetta A., Halouani K., Analytical modeling of electrochemical mechanisms in $\mathrm{CO}_{2}$ and $\mathrm{CO} / \mathrm{CO}_{2}$ producing Direct Carbon Fuel Cell. Journal of Electroanalytical Chemistry 668 (2012) 99-106.

[3] Zhang L., Xiao J., Xie Y., Tang Y., Liu J., Liu M., Behavior of strontium- and magnesiumdoped gallate electrolyte in direct carbon solid oxide fuel cells. Journal of Alloys and Compounds 608 (2014) 272-277.

[4] Munnings C., Kulkarni A., Giddey S., Badwal S.P.S., Biomass to power cor rsion in a ect carbon fuel cell. International Journal of Hydrogen Energy 39(23) (2014) 12 12385.

[5] Stähler M., Burdzik A., Calibration method for carbon dioxide sep ors t inves te direct methanol fuel cell efficiency. Journal of Power Sources 262 (20

[6] Qi J., Benipal N., Chadderdon D.J., Huo J., Jiang Y., Qiu Y. Aan X., Y.H. shanks B.H., Li W., Carbon nanotubes as catalysts for direct carbohydr $\triangle$ fuel cells, rbon 89 (2015)
142-147.

[7] Bruno M.M., Viva F.A., Petruccelli M.A., Corti M.R., Platinum ported on mesoporous carbon as cathode catalyst for direct methanol fue cells. Journal of ower Sources 278 (2015) 458-463.

[8] Antunes R., Skrzypkiewicz M., Chronoamperom inve agations of electro-oxidation of lignite in direct carbon bed solid oxide all. International Journal of Hydrogen Energy 40(12) (2015) 4357-4369.

[9] Giddey S., Kulkarni A., Munpinos C., 1 idwal S.P.S., Composite anodes for improved performance of a direct carbo fue 1l. Jour al of Power Sources 284 (2015) 122-129.

[10] Lee J.-Y., Song R.-H., L S. Park S.-J., Shul Y.G., Lee J.-W., A performance study of hybrid direct arbon fu vlls: Impact of anode microstructure. International Journal of Hydrogen Energ , 22) (2014) 149-11755.

[11] Rady A.C., Gid ${ }^{11}$ S.S., K. rni A., Badwal S.P.S., Bhattacharya S., Degradation Mechanism in a Direct $C$ arbon Fuel Cen, perated with Demineralised Brown Coal. Electrochimica Acta $143(2014,78-2$

[12] Bonaccorso a., Irvi J.T.S., Development of tubular hybrid direct carbon fuel cell. Int rmal no al of Hydrogen Energy 37(24) (2012) 19337-19344.

[13] on C Corre G., Antunes R., Irvine J.T.S., Scaling up of the hybrid direct carbon fuel cen hnology. International Journal of Hydrogen Energy 38(20) (2013) 8497-8502.

[14] Ruflin. erwich Ii A.D., Brett C., Berner J.K., Lux S.M., Direct carbon fuel cell: A proposed hybrid design to improve commercialization potential. Journal of Power Sources 213 (2012) $275-286$.

[15] Liu J., Wang H., Wu C., Zhao Q., Wang X., Yi L., Preparation and characterization of nanoporous carbon-supported platinum as anode electrocatalyst for direct borohydride fuel cell. International Journal of Hydrogen Energy 39(12) (2014) 6729-6736.

[16] Cao T., Wang H., Shi Y., Cai N., Direct carbon fuel conversion in a liquid antimony anode solid oxide fuel cell. Fuel 135 (2014) 223-227. 
[17] Yu X., Shi Y., Wang H., Cai N., Li C., Ghoniem A.F., Using potassium catalytic gasification to improve the performance of solid oxide direct carbon fuel cells: Experimental characterization and elementary reaction modeling. Journal of Power Sources 252 (2014) 130-137.

[18] Salernitano E., Giorgi L., Dikonimos Makris T., Direct growth of carbon nanofibers on carbon-based substrates as integrated gas diffusion and catalyst layer for polymer electrolyte fuel cells. International Journal of Hydrogen Energy 39(27) (2014) 15005-15016.

[19] Xu K., Chen C., Liu H., Tian Y., Li X., Yao H., Effect of coal based pyrolysis gases on the performance of solid oxide direct carbon fuel cells. International Journal of Hydrogen Energy 39(31) (2014) 17845-17851.

[20] Li C., Shi Y., Cai N., Effect of contact type between anode and carbonaceous f direct carbon fuel cell reaction characteristics. Journal of Power Sources 196(10) (011) 458593.

[21] Kacprzak A., Kobyłecki R., Włodarczyk R., Bis Z., The effect of fuel type on perform nce of a direct carbon fuel cell with molten alkaline electrolyte. Journal of Tower urces 255 (2014) 179-186.

[22] Zhang J., Jiang X., Piao G., Yang H., Zhong Z., Simulation of "yic bed el trode direct carbon fuel cell. International Journal of Hydrogen Energy $\quad$ (8) (2015, 213331.

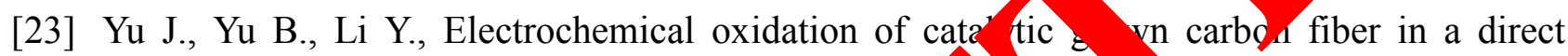
carbon fuel cell using $\mathrm{Ce}_{0.8} \mathrm{Sm}_{0.2} \mathrm{O}_{1.9}$-carbonate electro Interm
Energy 38(36) (2013) 16615-16622.

[24] Elleuch A., Yu J., Boussetta A., Halouani K., Li , Electroch/mical oxidation of graphite in an intermediate temperature direct carbon fu cell bas d on two-phases electrolyte. International Journal of Hydrogen Energ 38(20) (2 14-8523.

[25] Kulkarni A., Giddey S., Badwal S.P.S., Pa TO., trochemical performance of direct carbon fuel cells with titanate anodes. Electrochim acta), 21 (2014) 34-43.

[26] Ju H., Uhm S., Kim J.W., Sog K ., Choi H., Lee S.-H., Lee J., Enhanced anode interface for electrochemical oxidati f so d fuel in direct carbon fuel cells: The role of liquid Sn in mixed state. Journal of $r$ (2012) 36-41.

[27] Borghei M., Scotti anninen H, Jekman T., Anoshkin I.V., Nasibulin A.G., Franssila S., Kauppinen E.I., K llio Ruiz V., Lnhanced performance of a silicon microfabricated direct methanol fuel with Pt atalysts supported on few-walled carbon nanotubes. Energy 65 (2014) 612020.

[28] Huang Y., 's H., L Y., Xie Y., Liang Z., Liu C., Facile synthesis of poly(amidoamine)modifan car nano spheres supported Pt nanoparticles for direct methanol fuel cells.

J arna f Power arces 201(0) (2012) 81-87.

[29] D bpolito D., Hansen K.K., Enhancing Hybrid Direct Carbon Fuel Cell anode perto ance using $\mathrm{Ag}_{2} \mathrm{O}$. Electrochimica Acta 152 (2015) 222-239.

[30] Lee E.-1,., Chun H.H., Kim Y.-T., Enhancing Ni anode performance via $\mathrm{Gd}_{2} \mathrm{O}_{3}$ addition in molten carbonate-type direct carbon fuel cell. International Journal of Hydrogen Energy 39(29) (2014) 16541-16547.

[31] Li C., Lee E.K., Kim Y.-T., Lee D., Enhancing triple-phase boundary at fuel electrode of direct carbon fuel cell using a fuel-filled ceria-coated porous anode. International Journal of Hydrogen Energy 39(30) (2014) 17314-17321.

[32] Lee C.-G., Kim W.-K., Oxidation of ash-free coal in a direct carbon fuel cell. International Journal of Hydrogen Energy 40(15) (2015) 5475-5481. 
[33] Yu J., Zhao Y., Li Y., Utilization of corn cob biochar in a direct carbon fuel cell. Journal of Power Sources 270 (2014) 312-317.

[34] Yu X., Shi Y., Wang H., Cai N., Li C., Tomov R.I., Hanna J., Glowacki B.A., Ghoniem A.F., Experimental characterization and elementary reaction modeling of solid oxide electrolyte direct carbon fuel cell. Journal of Power Sources 243 (2013) 159-171.

[35] Dudek M., Tomov R.I., Wang C., Glowacki B.A., Tomczyk P., Socha R.P., Mosiałek M., Feasibility of direct carbon solid oxide fuels cell (DC-SOFC) fabrication by inkjet printing technology. Electrochimica Acta 105 (2013) 412-418.

[36] Kim J.-P., Choi H.-K., Chang Y.-J., Jeon C.-H., Feasibility of using ash-free coal in a solidoxide-electrolyte direct carbon fuel cell. International Journal of Hydrogen En $37(15)$ (2012) 11401-11408.

[37] Dudek M., Tomczyk P., Socha R., Hamaguchi M., Use of ash-free "Hyper-co. 9s a fuel or a direct carbon fuel cell with solid oxide electrolyte. International Jour al of Hyo en F lergy 39(23) (2014) 12386-12394.

[38] Deleebeeck L., Arenillas A., Menéndez J.A., Kammer Hansen 1d dired carbon fuel cell anode processes investigated using a 3-electrode half-ce setup. In ati hal Journal of Hydrogen Energy 40(4) (2015) 1945-1958.

[39] Choi S.H., Park D.-n., Yoon C.W., Yoon S.-P., Nam S Hong Shul Y.-G., Ham H.C., Han J., A study on the electrochemical performa ce of $100-\mathrm{cm}^{2}$ as direct carbon-molten carbonate fuel cell (DC-MCFC). International J urnal of Hydrogen Energy 40(15) (2015) 5144-5149.

[40] Eom S., Ahn S., Rhie Y., Kang K., Sung Y., M., Choi G., Kim D., Influence of devolatilized gases composition from rau cell) system. Energy 74 (2014) 734-740.

[41] Li X., Zhu Z., Chen J., De M R., Dick A., Bradley J., Lu G., Surface modification of carbon fuels for direct carbo fuel o ls. Jour M of Power Sources 186(1) (2009) 1-9.

[42] Zhang H., Chen L., Zho N., 11. ormance analysis of a direct carbon fuel cell with molten carbonate ele olyte. Ene 68 (2014) 292-300.

[43] Yuan W., Zhou B Hu Jeng J., 2hang Z., Tang Y., Passive direct methanol fuel cell using woven carbor ber fabi as mass transfer control medium. International Journal of Hydrogen Fnergy 40(5) (201, 2326-2333.

[44] Cinti G., H $\omega^{-S K}$ K., , tegration of direct carbon fuel cells with concentrated solar power. Inter ronal snal Hydrogen Energy 36(16) (2011) 10198-10208.

[45] aribi 1., Amai M., Pahlavanzadeh H., Kazemeini M., Investigation of carbon monoxide to anum nanoparticles in the presence of optimum ratio of doped polyaniline with toluene sulfonic acid and their utilization in a real passive direct methanol fuel cell. Electro, nica Acta 97 (2013) 216-225.

[46] Elleuch A., Halouani K., Li Y., Investigation of chemical and electrochemical reactions mechanisms in a direct carbon fuel cell using olive wood charcoal as sustainable fuel. Journal of Power Sources 281 (2015) 350-361.

[47] Jewulski J., Skrzypkiewicz M., Struzik M., Lubarska-Radziejewska I., Lignite as a fuel for direct carbon fuel cell system. International Journal of Hydrogen Energy 39(36) (2014) 21778-21785.

[48] Wang H., Cao T., Shi Y., Cai N., Yuan W., Liquid antimony anode direct carbon fuel cell fueled with mass-produced de-ash coal. Energy 75 (2014) 555-559. 
[49] Li C., Shi Y., Cai N., Mechanism for carbon direct electrochemical reactions in a solid oxide electrolyte direct carbon fuel cell. Journal of Power Sources 196(2) (2011) 754-763.

[50] Zhou J., Ye X.F., Shao L., Zhang X.P., Qian J.Q., Wang S.R., A promising direct carbon fuel cell based on the cathode-supported tubular solid oxide fuel cell technology. Electrochimica Acta 74 (2012) 267-270.

[51] Javadekar A., Jayakumar A., Pujara R., Vohs J.M., Gorte R.J., Molten silver as a direct carbon fuel cell anode. Journal of Power Sources 214 (2012) 239-243.

[52] Cao J., Wang L., Song L., Xu J., Wang H., Chen Z., Huang Q., Yang H., Novel cathodal diffusion layer with mesoporous carbon for the passive direct methanol fuel cell. Electrochimica Acta 118 (2014) 163-168.

[53] Dudek M., On the utilization of coal samples in direct carbon solid oxide fu cell techn gy. Solid State Ionics 271 (2015) 121-127.

[54] Xu X., Zhou W., Liang F., Zhu Z., Optimization of a direct carbo fuel cell op ration below $700{ }^{\circ} \mathrm{C}$. International Journal of Hydrogen Energy 38(13)

[55] Zhao M., Zhang H., Hu Z., Zhang Z., Zhang J., Performance raracte cs of a direct carbon fuel cell/thermoelectric generator hybrid system. Energy version an anagement 89 (2015) 683-689.

[56] Giddey S., Kulkarni A., Munnings C., Badwal S. P.s., Nerforma Raluation of a tubular direct carbon fuel cell operating in a packed bed o carbon. Energy 68 (2014) 538-547.

[57] Kouchachvili L., Ikura M., Performance of dire carbon fue cell. International Journal of Hydrogen Energy 36(16) (2011) 10263-10268.

[58] Li X., Zhu Z., De Marco R., Bradley J., Evaluation of raw coals as fuels for direct carbon fuel cells. Journal of Power Source 19 (2010) 4051-4058.

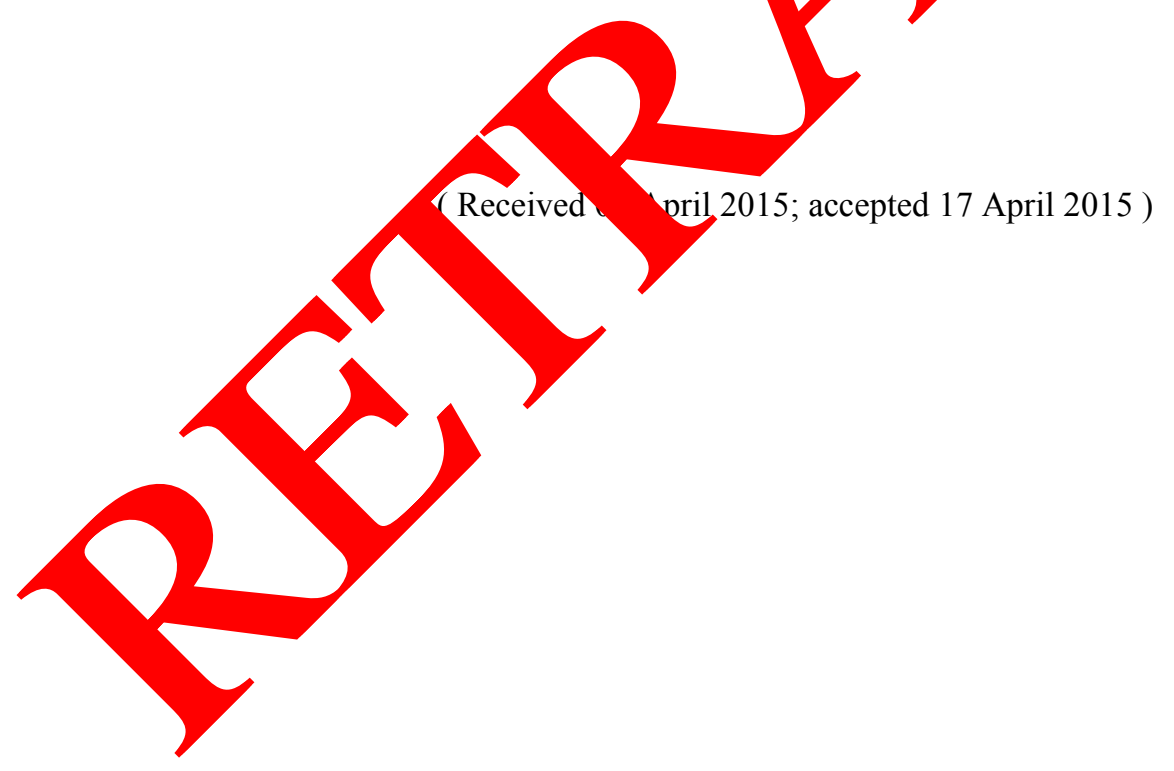

